\title{
Potensi Larva Hermetia illucens sebagai Pereduksi Limbah Industri Pengolahan Hasil Perikanan
}

\section{The Potential of Hermetia illucens Larvae as Reducer of Industrial Fish Processing Waste}

\author{
Arif R. Hakim ${ }^{* 1}$, Agus Prasetya ${ }^{2}$ \& Himawan T.B.M. Petrus ${ }^{2}$ \\ ${ }^{1}$ Mahasiswa Prodi Magister Teknik Sistem Universitas Gadjah Mada \\ Jl. Teknika Utara No.3, Sleman, Yogyakarta \\ ${ }_{2}$ Departemen Teknik Kimia Universitas Gadjah Mada \\ JI. Grafika No. 2 Kampus UGM, Yogyakarta 55281 \\ *Penulis untuk korespondensi, email: arifrahmanh11@gmail.com
}

\begin{abstract}
Abstrak
Limbah organik dari industri pengolahan ikan bisa menjadi masalah serius jika tidak ditangani dengan baik, karena jumlahnya yang terus meningkat setiap tahun. Padahal kandungan nutrisinya masih tinggi, terutama kadar proteinnya. Proses biokonversi bahan organik dari limbah diharapkan mampu menjadi solusi permasalahan limbah industri dan bisa meningkatkan nilai tambahnya. Biokonversi menggunakan larva serangga Hermetia illucens mempunyai banyak keunggulan dibandingkan proses konversi lainnya. Tujuan dari penelitian ini adalah untuk mengetahui kemampuan larva dalam mengurangi limbah dari industri perikanan. Limbah yang digunakan ialah kepala ikan tuna. Dengan variasi perlakuan jumlah kepala tuna sebagai pakan larva yaitu 60, 80 dan $100 \mathrm{mg} / \mathrm{larva} / \mathrm{hari}$. Larva yang digunakan sebanyak 200 ekor dan dilakukan pengulangan perlakuan sebanyak 3 kali. Waktu pengamatan dan pemeliharaan larva selama 19 hari, kemudian dihitung substrate reduction, waste reduction index (WRI), bobot larva serta kandungan protein dan lemak dari larva. Hasil pengamatan menunjukkan bahwa jumlah pakan optimum ialah $60 \mathrm{mg} / \mathrm{larva} / \mathrm{hari}$, meliputi parameter substrate reduction $77,09 \%$, WRI 4,06\%/hari, bobot larva $72,59 \mathrm{mg}$, kandungan protein $25,38 \%$ (berat basah) dan kandungan lemak $6,85 \%$ (berat basah). Berdasarkan hasil tersebut bisa disimpulkan bahwa larva memiliki potensi sebagai agen pengurai limbah industri pengolahan perikanan.
\end{abstract}

Kata kunci: Biokonversi, larva Hermetia illucens, limbah industri perikanan

\begin{abstract}
Organic waste from processing fishery products can be a serious problem if not handled properly, as the number increases every year. Though the content of nutrients in the waste is still high, especially protein content. The bioconversion process of organic matter from the waste is expected to be able to overcome the problems of industrial waste and increase its added value. Bioconversion using insect larvae Hermetia illucens has many advantages than other conversion processes. The purpose of this study was to determine the ability of larvae in reducing the waste fishery industry. Waste used in this study was head of the tuna, with feeding rates of 60 , 80 and $100 \mathrm{mg} / \mathrm{larva} /$ day. 200 larvae were used in each treatment and 3 replications. Observation time and culturing of larvae was 19 days then calculated substrate reduction, waste reduction index (WRI), the weight of larvae and protein and lipids content. The result of observations showed that feeding rate $60 \mathrm{mg} / \mathrm{larva} / \mathrm{day}$ give optimum on parameters. The substrate reduction was $77.09 \%$, WRI 4.06 (\% / day), the weight of larva was $72.59 \mathrm{mg}$. Protein content $25.38 \%$ (wb) and lipids $6.85 \%$ (wb). According to that result, it could be to concluded that larvae have potential as an agent of reducing of waste fishery products.
\end{abstract}

Keywords: Bioconversion, Hermetia illucens larvae, waste of fishery industry

\section{Pengantar}

Berbagai kebijakan pemerintah terkait pengembangan perikanan semakin masif dilakukan diantaranya upaya pemberantasan IUU (illegal, unreported and unregulated) Fishing, pengelolaan sumberdaya ikan di 11 wilayah pengelolaan perikanan Negara Republik Indonesia (WPPNRI) dan peningkatkan mutu, diversifikasi, akses pasar produk kelautan dan perikanan (Permen KP, 2015). Dampak dari kebijakan-kebijakan tersebut memacu peningkatan produksi perikanan laut maupun darat serta produkproduk olahan perikanan (Pudjiastuti, 2016). Dalam perdagangan ikan internasional, Badan Pusat Statisik (2016) mencatat bahwa nilai ekspor komoditas perikanan semester I tahun 2016 mencapai US\$ 2.070.827.218 atau meningkat 3,73\% dibandingkan 
periode yang sama pada tahun 2015. Hal peningkatan nilai ekspor tersebut menunjukkan bahwa kinerja industri perikanan nasional saat ini berada pada kondisi meningkat.

Seiring dengan pertumbuhan industri pengolahan hasil perikanan tentu akan diikuti oleh peningkatan limbah yang dihasilkan. Peranginangin et al. (2011), menyebutkan isu lingkungan yang menjadi perhatian dunia ialah tuntutan pengelolaan hasil perikanan ke arah green production. Hal ini bisa diartikan bahwa perlu adanya optimalisasi pemanfaatan ikan menjadi sesuatu yang bernilai tambah dan menekan limbah yang dihasilkan dengan mengolah menjadi produk bermanfaat. Menurut Retnowati (2011), sisa hasil pengolahan komoditas utama berupa ikan tuna diperkirakan mencapai 716.531 ton dari total produksi bersih UPI (unit pengolahan ikan) sebesar 3.876.796 ton atau sekitar 24\%. Pengolahan ikan yang menghasilkan sisa paling banyak ialah fillet, pengalengan dan pembekuan. Porsi bagian ikan yang terbuang pada proses pengolahan menjadi produk fillet yaitu sisa daging $50 \%$, kepala $20 \%$, isi perut $13 \%$, tulang 9\%, kulit 6\% dan lainnya $2 \%$ (Trilaksani, 2011; Ghaly et al., 2013). Sedangkan menurut Bezema et al. (2012) jenis pengolahan pengalengan tuna menghasilkan limbah padat sebesar 29\%. Besarnya limbah pengolahan menjadi masalah lingkungan yang serius bila tidak ditangani dengan baik dan benar. Pengolahan limbah hasil pengolahan ikan seharusnya bisa ditingkatkan nilai tambahnya, karena nutrisi yang terkandung limbah padat tersebut masih tinggi.

Disisi lain, pertumbuhan perikanan budidaya tidak diimbangi dengan petumbuhan pengolahan pakan nasional, padahal biaya terbesar usaha budidaya ialah pada biaya pakan. Presentase kebutuhan pakan bisa mencapai $60-70 \%$ dari total biaya produksi (Widodo \& Fakhri, 2015). Hal ini mengakibatkan, kebutuhan bahan pakan ikan dicukupi dengan jalan impor. Kajian Direktorat Kelautan dan Perikanan Bappenas (2014) menyatakan dampak dari impor pakan ikan menyebabkan biaya produksi meningkat, sehingga membutuhkan modal usaha yang lebih besar. Keuntungan pembudidaya berkurang dan usaha budidaya ikan skala kecil akan mengalami degradasi hingga menuju kebangkrutan. Laporan dari Word Bank (2013) tentang prospek perikanan tangkap dan budidaya tahun 2030, menyebutkan bahwa kebutuhan impor pakan ikan/tepung ikan pada tahun 2010 mencapai 257.000 ton dan diprediksi akan meningkat menjadi 416.000 ton pada tahun 2020 . Indonesia sendiri pada bulan oktober tahun 2015 tercatat sudah mengimpor tepung ikan sebanyak 121.735 ton (Pusdatin KKP, 2015).

Salah satu alternatif untuk meningkatkan ketersediaan bahan pakan secara mandiri adalah memanfaatkan limbah padat industri pengolahan ikan menjadi sumber protein untuk bahan pakan ikan melalui proses biokonversi. Newton et al. (2005) menjelaskan dalam proses ini limbah organik akan di konversi menjadi senyawa sederhana baik protein maupun lemak, melalui proses fermentasi yang melibatkan organisme hidup. Proses ini biasanya dikenal sebagai penguraian secara anaerob. Organisme yang berperan dalam proses biokonversi ini umumnya adalah bakteri, jamur dan larva serangga (family: Chaliforidae, Mucidae, Stratiomydae). Limbah-limbah hewani agen perombak yang sering ditemukan adalah larva serangga Diptera dari famili Challifora. Larva serangga dari famili: Stratiomydae, Genus: Hermetia, spesies: Hermetia illucens (Fahmi et al., 2009).

Penelitian yang menyatakan bahwa larva Hermetia illucens memberikan banyak kelebihan dalam mereduksi limbah organik dan berguna sebagai bahan pakan ikan telah banyak dilakukan (Diener et al., 2009; Rahmawati et al., 2010; Saragi et al., 2015, Fahmi, 2015; Li et al., 2016). Larva Hermetia illucens kandungan nutrisi mencapai $45-50 \%$ dan 24$30 \%$ masing-masing untuk protein dan lemak (Fahmi, 2015). Pada awal penelitian Hermetia illucens media yang digunakan untuk pertumbuhannya ialah bungkil kelapa sawit (PKM) kemudian terus berkembang hingga menggunakan limbah-limbah organik sampah industri dan perkotaan (Saragi et al, 2015). Myers et al. (2008) dan Sheppard et al. (1994) melaporkan larva Hermetia illucens mampu mereduksi 33-58\% kandungan organik pada kotoran sapi dan $50 \%$ dari kotoran ayam. Sedangkan Diener et al. (2011) menyatakan sampah organik perkotaan mampu dikurangi hingga $70 \%$.

Biokonversi menggunakan larva Hermetia illucens pada media limbah ikan juga sudah dilakukan oleh Fahmi (2015) dan Saragi et al. (2015). Dalam laporan riset tersebut tidak spesifik menjelaskan sumber limbah ikan yang digunakan apakah dari industri pengolahan atau dari limbah domestik kuliner, sehingga belum diketahui secara jelas berapa laju konversi bahan limbah pengolahan ikan dalam periode tertentu. Belum adanya informasi komposisi media yang optimal jika menggunakan limbah pengolahan ikan untuk tumbuh kembang larva Hermetia illucens juga menjadi permasalahan yang belum terselesaikan

\section{Bahan dan Metode}

Bahan utama penelitian ini adalah larva Hermetia illucens (Diptera: Stratiomyidae). Larva diperoleh dari produksi telur serangga Hermetia illucens hasil produksi di Laboratorium pakan alami Balai Penelitian 
dan Pengembangan Budidaya Ikan Hias, Depok Jawa Barat. Limbah yang di direduksi berupa kepala ikan tuna. Limbah diperoleh dari industri pengalengan ikan tuna di Kabupaten Pasuruan Jawa Timur. Limbah di peroleh dari pabrik pengalengan tuna. Limbah di bawa ke tempat penelitian dalam kondisi dingin $\left(0-5^{\circ} \mathrm{C}\right)$.

Penelitian ini dimulai dengan persiapan media untuk penetasan telur Hermetia illucens. Media berupa campuran dedak dan sayuran (wortel, kacang panjang, sawi, kol). Selanjutnya telur diletakkan pada media yang telah disiapkan dengan alas kertas, telur menetas dalam waktu 2-3 hari. Larva yang muncul dikultivasi selama 6 hari dalam media tersebut sebelum dipanen. Larva usia 6 hari kemudian dijadikan agen biokonversi limbah industri perikanan. Selama proses kultivasi larva, dipersiapan juga media untuk bahan yang akan dikonversi atau substrat pakan larva. Media tersebut berupa kepala ikan tuna, kemudian dicuci bersih dengan air tawar dan dilakukan pengecilan ukuran atau pemotongan hingga ukuran 1-2 cm. Media ini lalu disimpan dalam freezer sebelum digunakan. Larva yang diperoleh dengan usia 6 hari selanjutnya di berikan perlakuan pakan harian menggunakan media limbah yang telah dipersiapkan selama 19 hari masa pemeliharaan. Jumlah pakan kepala ikan tuna yang diberikan ke larva sebesar 60, 80 dan 100 mg/larva. Parameter yang di amati substrate reduction, waste reduction index (WRI), bobot larva serta kandungan protein dan lemaknya.

\section{Analisa}

\section{Substrate consumption}

Substrat/media/pakan yang diberikan pada larva kemudian sisa setelah 3 hari timbang beratnya lalu bagi dengan jumlah berat awal pakan yang diberikan.

$$
\text { Substrate consumption }=\frac{W_{0}-W_{t}}{W_{0}} \times 100 \%
$$

Dimana: $\mathrm{W}_{0}=$ Berat substrat awal

$$
\mathrm{W}_{\mathrm{t}} \text { = Berat substrat akhir }
$$

\section{Waste reduction index (WRI)}

Nilai pengurangan sampah dihitung berdasarkan persamaan yang dikemukakan Dienner (2009) yaitu:

$$
\begin{aligned}
& W R I=\frac{D}{t} \times 100 \% \\
& D=\frac{W-R}{W}
\end{aligned}
$$

Dimana:

$\mathrm{W}=$ penurunan substrat keseluruhan $(\mathrm{mg})$

$\mathrm{t} \quad=$ total waktu larva memakan substrat (hari)

$\mathrm{R}$ = sisa substrat setelah waktu tertentu (mg)

\section{Bobot larva}

Pengukuran berat larva Hermetia illucens dilakukan setiap hari dan dicatat dalam jurnal pemantauan berat larva, hasil dari pengukuran berat larva ditotal dan dibagi dengan jumlah larva yang diukur untuk mencari berat rata-rata larva setiap 3 hari.

$$
\text { Berat rata-rata }=\frac{\text { Total berat larva }}{\text { Jumlah total larva }}
$$

\section{Proksimat}

Uji proksimat meliputi kadar protein dan kadar lemak. Metode yang digunakan merujuk pada metode AOAC - Official Method of Analysis (2006).

\section{Analisa Data}

Data yang diperoleh selanjutnya dianalisa statistik dengan Anova, selang kepercayaan 95\%, dan uji lanjut menggunakan Tukey). Analisa statistic menggunakan bantuan software Minitab 17

\section{Hasil dan Pembahasan}

\section{Konversi limbah}

Substrate consumption ialah jumlah pakan yang dikonsumsi larva yang dinyatakan dalam persen selama masa pemeliharaan. Pemberian pakan kepada larva Hermetia illucens berupa kepala ikan sebesar 60, 80 dan 100 mg/larva/hari menghasilkan nilai substrate consumption sebesar $64.02-77.09 \%$ (Tabel 1). Nilai tertinggi pada perlakuan K60 dengan nilai $77.09 \%$. dan terendah pada perlakuan K100 dengan nilai $64.02 \%$.

Nilai substrate consumption cenderung menurun dengan meningkatnya jumlah pakan yang diberikan kepada larva. Hasil analisa menunjukkan bahwa perlakuan perbedaan jumlah pakan memberikan pengaruh yang nyata terhadap nilai substrate consumption $(P<0,05)$. Nilai perbedaan tersaji pada tabel 1 berupa perbedaan notasi huruf yang berbeda. Berdasarkan nilai tersebut pemberian pakan sebanyak 60 mg/larva/hari merupakan jumlah paling optimal untuk pengurangan substrate.

Tabel 1. Substrate Consumption.

\begin{tabular}{cc}
\hline Perlakuan & Substrate consumption $(\%)$ \\
\hline K60 & $77.09 \pm 1.0^{\mathrm{a}}$ \\
K80 & $68.23 \pm 5.59^{\mathrm{ab}}$ \\
K100 & $64.02 \pm 2.67^{\mathrm{bc}}$ \\
\hline
\end{tabular}

Keterangan: superscript dengan huruf berbeda pada kolom yang sama menunjukkan berbeda nyata pada $P<0,05$

$\mathrm{K} 60$ = Pemberian pakan kepala $60 \mathrm{mg} / \mathrm{hari}$

$\mathrm{K} 80=$ Pemberian pakan kepala $80 \mathrm{mg} / \mathrm{hari}$

$\mathrm{K} 100$ = Pemberian pakan kepala $100 \mathrm{mg} /$ hari 
Kecenderungan ini senada dengan penelitian sebelumnya (Diener et al., 2009; Supriyana et al., 2016; Manurung et al., 2016) bahwa nilai substrate reduction akan turun jika jumlah pakan/media yang diberikan pada larva Hermetia illucens meningkat.

Nilai substrate consumption selanjutnya digunakan untuk menentukan nilai waste reduction index (Diener et al., 2009). Nilai ini adalah untuk menghitung kemampuan substrate consumption dengan mempertimbangkan waktu/periode pemberian pakan. Nilai waste reduction index (WRI) pada tabel 2, memberikan informasi bahwa nilai tertinggi adalah sebesar 4.06 pada perlakuan K60 dan terendah sebesar 3.37 pada perlakuan K100. Jumlah pakan yang diberikan pada $\mathrm{K} 60$ bisa di konsumsi oleh larva sacara optimal dibandingkan perlakuan lain. Nilai WRI ini berbanding lurus dengan nilai substrate consumption. Pada perlakuan pakan dengan jumlah lebih tinggi maka nilai WRI cenderung turun, hal ini di mungkinkan larva sudah tidak mampu lagi mengkonsumsi pakan yang diberikan sehingga nilai presentase pakan yang dikonsumsi terhadap total pakan menjadi lebih rendah.

Tabel 2. Waste Reduction Index.

\begin{tabular}{cc}
\hline Perlakuan & Waste reduction index \\
\hline K60 & $4.06 \pm 0.05^{\mathrm{a}}$ \\
K80 & $3.59 \pm 0.29^{\mathrm{ab}}$ \\
K100 & $3.37 \pm 0.14^{\mathrm{bc}}$ \\
\hline
\end{tabular}

Keterangan: superscript dengan huruf berbeda pada kolom yang sama menunjukkan berbeda nyata pada $\mathrm{P}<0,05$.

$\mathrm{K} 60$ = Pemberian pakan kepala $60 \mathrm{mg} /$ hari $\mathrm{K} 80=$ Pemberian pakan kepala $80 \mathrm{mg} /$ hari $\mathrm{K} 100=$ Pemberian pakan kepala $100 \mathrm{mg} /$ hari

\section{Bobot larva}

Perbedaan bobot larva terjadi hingga masa pemeliharaan di akhiri yaitu hari ke 19. Detail bobot akhir larva bisa di lihat pada tabel 3 . Bobot tertinggi pada perlakuan K100 yaitu $95.04 \mathrm{mg} / \mathrm{larva}$ dan terendah pada perlakuan K60 yaitu 72.59 mg/larva. Berdasarkan analisa Anova dengan uji lanjut Tukey selang kepercayaan 95\%, bahwa perlakuan K100 tidak berbeda nyata dengan perlakuan K60 dan K80.

Perbedaan jumlah pakan tidak memberikan perbedaan pada bobot larva BSF. Hal ini dimungkinkan karena konsumsi pakan yang terhitung berdasarkan substrate consumption tidak memberikan perbedaan yang nyata, artinya larva sudah cukup dengan jumlah pakan sebesar minimal $60 \mathrm{mg} / \mathrm{larva} /$ hari. Jika pakan ditambah maka larva tidak akan memakannya sehingga tidak akan menambah bobot larva.
Tabel 3. Bobot akhir larva.

\begin{tabular}{cc}
\hline Perlakukan & Bobot larva $(\mathrm{mg})$ \\
\hline K60 & $72.59 \pm 6.04^{\mathrm{ab}}$ \\
K80 & $82.99 \pm 13.35^{\mathrm{ab}}$ \\
K100 & $95.04 \pm 11.68^{\mathrm{a}}$ \\
\hline
\end{tabular}

Keterangan: superscript dengan huruf berbeda pada kolom yang sama menunjukkan berbeda nyata pada $\mathrm{P}<0,05$.

$\mathrm{K} 60=$ Pemberian pakan kepala $60 \mathrm{mg} / \mathrm{hari}$

$\mathrm{K} 80=$ Pemberian pakan kepala $80 \mathrm{mg} / \mathrm{hari}$

$\mathrm{K} 100=$ Pemberian pakan kepala $100 \mathrm{mg} /$ hari

\section{Proksimat larva}

Selanjutnya larva yang telah berumur 6 hari di pindahkan ke media / pakan berupa limbah ikan jumlah yang digunakan bervariasi yaitu 60,80 dan $100 \mathrm{mg} / \mathrm{larva} /$ hari. Masa pemeliharaan selama 19 hari dan di analisa proksimat biomassa larva setelah panen. Hasil analisa proksimat meliputi protein dan lemak di sajikan pada tabel 3 .

Tabel 4. Komposisi proksimat larva Hermetia illucens.

\begin{tabular}{ccccc}
\hline $\begin{array}{c}\text { Parameter } \\
(\% \mathrm{bb})\end{array}$ & $\begin{array}{c}\text { Larva } \\
\text { awal }\end{array}$ & $\mathrm{K} 60$ & $\mathrm{~K} 80$ & $\mathrm{~K} 100$ \\
\hline Protein & 0.35 & 25.38 & 22.24 & 22.72 \\
Lemak & 0.66 & 6.85 & 6.12 & 8.77 \\
\hline
\end{tabular}

Keterangan: $\mathrm{Bb}=$ berat basah

Terjadi kenaikan pada kadar protein dan lemak larva usia panen dibandingkan dengan larva awal. Nilai protein berkisar antara $22.24-25.38 \%$, tertinggi pada perlakuan pakan dengan jumlah $60 \mathrm{mg} / \mathrm{larva} / \mathrm{hari}$ yaitu $25.38 \%$. Sedangkan nilai protein terendah yaitu $22.24 \%$ pada perlakuan pakan kepala $80 \mathrm{mg} / \mathrm{larva} /$ hari. Pakan yang diberikan pada larva memiliki kadar protein sebesar $23.43-25.58 \%$, data ini menunjukkan bahwa larva Hermetia illucens mampu menyerap protein yang ada di pakan dengan baik. Kondisi hampir sama terjadi pada kadar lemak, pada awal pemeliharaan rata-rata kadar lemak larva hanya sebesar $0.66 \%$ lalu meningkat setelah di berikan perlakuan pakan berupa limbah ikan, pada akhir masa pemeliharaan kadar lemak larva menjadi $6.12-8.77 \%$.

Kemampuan larva Hermetia illucens untuk memakan berbagai jenis bahan organik kemudian merubahnya menjadi protein, lemak maupun kalori adalah karena keberadaan enzim protease, lipase dan amylase dalam sistem pencernaannya (Kim et al., 2011). Sehingga biomassa larva akan memiliki kandungan nutrisi yang kurang lebih sama dengan kandungan nutrisi pakan yang diberikan. 
Perbedaan nutrisi pada pakan akan menyebabkan kandungan nutrisi pada larva berbeda-beda. Tomberlin et al. (2002) mengemukakan bahwa nutrisi larva Hermetia illucens sangat dipengaruhi oleh media tempat mereka berkembang biak. Bila media tersebut kaya protein maka larva akan mengandung tinggi protein, demikian pula bila media kaya akan lemak maupun serat. Demikian juga hasil penelitian Tschirner \& Simon (2014), yang menyebutkan kandungan nutrisi larva Hermetia illucens ditentukan oleh pakan yang di konsumsi. Larva Hermetia illucens mampu merubah menjadikan protein dan lemak sebagai sumber energi sebaik dengan konversi energi dari karbohidrat (Diener et al., 2009).

\section{Kesimpulan}

Berdasarkan hasil penelitian diperoleh bukti bahwa larva mampu mereduksi limbah pengolahan ikan berupa kepala ikan tuna hingga $77.09 \%$ selama 19 hari, dengan waste reduction index (WRI) 4.06 (\%/ hari) yang dihasilkan bobot larva $H$. illucens sebesar $95.04 \mathrm{mg} / \mathrm{larva}$. Kadar protein yang terkandung dalam larva sebesar $25.38 \%$ dan lemak sebesar $6.85 \%$.

\section{Ucapan Terimakasih}

Penulis mengucapkan terima kasih kepada Loka Riset Mekanisasi Pengolahan Hasil Perikanan yang telah memfasilitasi sarana penelitian, serta pada rekan-rekan Magister Teknik Sistem UGM angkatan 2015 yang senantiasa memberi masukan dan saran pada penelitian ini.

\section{Daftar Pustaka}

Bappenas. 2014. Kajian Strategi Pengelolaan Perikanan Berkelanjutan. Kementerian PPN / Bappenas Direktorat Kelautan dan Perikanan

Bezama, A., H. Valeria., M. Correa \& N. Szarka. 2012. Evaluation of the environmental impacts of a Cleaner Production Agreement by frozen fish facilities in the Biobío Region, Chile. J. Clean. Prod. 26: 95-100

Diener, S., C. Zurbrügg \& K. Tockner. 2009. Conversion of organic material by black soldier fly larvae-establishing optimal feeding rates. Waste Management \& Research 27: 603-610

Diener, S., S. Solano., R. Gutiérrez., C. Zurbrugg \& K. Tockner. 2011. Biological treatment of municipal organic waste using black soldier fly larvae. Waste and Biomass Valorization 2: 357363
Fahmi, M.R., S. Hem \& I.W. Subamia. 2009. Potensi Maggot untuk Peningkatan Pertumbuhan dan Status Kesehatan Ikan. J. Riset Akuakultur. 4: 221-232

Fahmi, M.R. 2015. Optimalisasi proses biokonversi dengan menggunakan mini-larva Hermetia illucens untuk memenuhi kebutuhan pakan ikan. Pros Sem Nas Masy Biodiv Indon. 1: 139-144

Ghaly, A.E., V.V Ramakrishnan., M.S. Brooks., S.M. Budge \& D. Dave. 2013. Fish processing wastes as a potential source of proteins, amino acids and oils: a critical review. J. Microb. Biochem. Technol. 5: 107-129

Kim, W., Bae, S., Park, K., Lee, S., Choi, Y., Han,S., Koh, Y. 2011. Biochemical characterization of digestive enzymes in the black soldier fly, Hermetia illucens (Diptera: Stratiomyidae). J. of Asia-Pasific Entomology. 14. 11-14

Li, S., H. Ji., B. Zhang., J. Tian., J. Zhou \& H. Yu. 2016. Influence of black soldier fly (Hermetia illucens) larvae oil on growth performance, body composition, tissue fatty acid composition and lipid deposition in juvenile Jian carp (Cyprinus carpio var. Jian). J. Aquaculture. 465: 43-52

Manurung, R., A. Supriatna., R.R. Esyanthi \& R.E. Putra. 2016. Bioconversion of Rice straw waste by black soldier fly larvae (Hermetia illucens L.): Optimal feed rate for biomass production. J. of Entomology and Zoology Studies. 4: 1036-1041

Myers, H.M., J.K. Tomberlin., B.D. Lambert \& D. Kattes. 2008. Development of black soldier fly (Diptera: Stratiomyidae) larvae fed dairy manure. Environmental Entomology. 37: 11-15

Newton, L., C. Sheppard., D.W. Watson., G. Burtle \& R. Dove. 2005. Using the black soldier fly, Hermetia illucens, as a value- added tool for the management of swine manure. Report for The Animal and Poultry waste Management Center. North Carolina State University Raleigh

Peranginangin, R., Agusman \& A. Poernomo. 2011. Penelitian dan Pengembangan Pengolahan Hasil Samping Industri Perikanan. Analisis Kebijakan. Pengembangan Industri Pengolahan Hasil Perikanan dan Kelautan. Balitbang. KKP

Peraturan Menteri Kelautan dan Perikanan Republik Indonesia Nomor 45/PERMEN-KP/2015. Perubahan atas peraturan menteri kelautan dan perikanan republik Indonesia nomor 25/permen$\mathrm{kp} / 2015$ tentang rencana strategis kementerian kelautan dan perikanan tahun 2015-2019

Pudjiastuti, S. 2016. Pidato Penganugerahan 
Doktor Honoris Causa. Pemberantasan Illegal, Unreported, and Unregulated Fishing: menegakkan kedaulatan dan menjaga keberlajutan untuk kesejahteraan bangsa Indonesia. Universitas Diponegoro. Semarang

Pusat Data dan Informasi Kementerian Kelautan Perikanan. 2015. Kelautan dan Perikanan dalam angka 2015.

Rachmawati., D. Buchori., P. Hidayat., S. Hem \& M.R. Fahmi. 2010. perkembangan dan kandungan nutrisi larva Hermetia illucens (Linnaeus) (Diptera: Stratiomyidae) pada bungkil kelapa sawit. J. Entomol. Indon. 7: 28-41

Retnowati, N. 2011. Kebijakan pemanfaatan limbah hasil perikanan. Disampaikan pada Focus Group Discussion "mengubah limbah perikanan menjadi hasil samping yang bernilai tambah". Balai besar penelitian dan pengembangan pengolahan produk dan bioteknologi kelautan dan perikanan. Jakarta

Saragi, E.S \& A.Y. Bagastyo. 2015. Reduction of Organic Solid Waste by Black Soldier Fly (Hermetia illucens) Larvae. The 5th Environmental Technology and Management Conference "Green Technology towards Sustainable Environment".Bandung, Indonesia

Sheppard, D.C., G.L. Newton., S.A. Thompson \& S. Savage. 1994. A value-added manure management-system using the black soldier fly. Bioresource Technology 50: 275-279

Tomberlin, J.K., D.C. Sheppard \& J.A. Joyce. 2002. Selected life-history traits of Black Soldier Flies (Diptera: Stratiomyidae) reared on three artificial diets. Ann Entomol Soc Am. 95: 379-386

Trilaksani, W. 2011. Isu terkini dan inovasi teknologi pemanfaatan limbah perikanan. Disampaikan pada Focus Group Discussion "mengubah limbah perikanan menjadi hasil samping yang bernilai tambah". Balai besar penelitian dan pengembangan pengolahan produk dan bioteknologi kelautan dan perikanan. Jakarta

Tschirner, M \& A. Simon. 2015. Influence of different growing substrates and processing on the nutrient composition of black soldier fly larvae destined for animal feed. J. of Insects as Food and Feed. 1: 249-259

Widodo, M.S \& M.R. Fakhri. 2015. Pemanfaatan pakan organik pada budidaya lele dumbo (Clarias gariepinus) di Kabupaten Probolinggo. J. of Innovation and Applied Technology. 1: 159163

Word Bank Report. 2013. Fish to 2030; Prospects for Fisheries and Aquaculture. Agriculture and Environmental Services Discussion Paper 03. Number 83177-GLB 